\title{
In Memoriam Merle Calvin Ricklefs
}

\author{
(17 July 1943-29 December 2019)
}

\author{
Martin van Bruinessen \\ Utrecht University, Utrecht, The Netherlands \\ m.vanbruinessen@uu.nl
}

In the last days of 2019, the sad news reached us that Merle Ricklefs had passed away, after a long and painful disease that had not, however, stopped him from working, almost until the end. He had seen the last of his planned books, Soul catcher:Java's fiery Prince Mangkunagara I, through the press (it was published in 2018) and sent off his last two articles to the journal Archipel, while maintaining a lively correspondence with colleagues and friends about these final contributions. Sad though his departure is, he successfully completed what he had set out to accomplish in terms of published work.

How should one begin to describe Merle Ricklefs as a scholar: Australian historian of Indonesia? It is true that he spent the major part of his teaching career in Australia, holding prominent appointments at three of the country's best universities: Monash, ANU, and Melbourne. But he was not really rooted in any Australian academic tradition and did not leave much of a mark on Australia's academic engagement with Indonesia. American by birth and education, with a PhD from Cornell University's prestigious Southeast Asian Studies programme (obtained in 1973), he carried out library and archival research in Indonesia, England, and the Netherlands and had his first teaching appointment at SOAS in London (1969-1979) before starting at Monash University in 1980. He thus had extensive exposure to, and was intellectually shaped by, the academic environments of three continents, to which we might add Singapore, where he spent the best part of a decade at the very end of his career before finally retiring to his home in Melbourne.

Ricklefs's first published article, written as a PhD student at Cornell, concerned Cambodian epigraphy, but quite soon he turned to the subject that would remain at the core of his interests for his entire career: the history of the Central Javanese kingdoms of the eighteenth, and later also nineteenth, century. His main thesis adviser at Cornell was the historian Oliver W. Wolters, a specialist in early states in Sumatra and mainland Southeast Asia. For his 
research, Ricklefs had to go to the places where the primary sources were to be found, the libraries and archives of Indonesia, Great Britain, and the Netherlands. As mentors, he sought out the men who were most familiar with these sources. Unsurprisingly, these were Dutch scholars of Javanese history and culture. In his dissertation, he acknowledges his profound debt to C.C. Berg, H.J. de Graaf, Th.G.Th. Pigeaud, and P.J. Zoetmulder for their contributions to his understanding of Javanese history, language, literature, and society and thanks them for the 'training, advice, criticism and encouragement which [had] inspired and sustained' him. These men were no doubt the most knowledgeable scholars on the subject in their day, but they can hardly be said to constitute a distinct 'school' of Javanese or Indonesian studies. Berg had recently retired from a full professorship at Leiden, but the other three were rather isolated, and their qualities not fully appreciated, in the Dutch academic environment. Ricklefs was, in fact, probably the only graduate student they trained or advised, and he consciously set out to emulate and expand upon their work. It was his ambition to combine De Graaf's mastery of Dutch archival materials on Java, Pigeaud's encyclopaedic knowledge of Javanese language, literature, and manuscripts, and Zoetmulder's subtle understanding of the mystical and cosmological dimension of this literature.

In the obituary he later wrote for De Graaf (1985), he praises him as the 'father of the field' in spite of his never having trained students, and De Graaf's 1956 edition of De vijf gezantschapsreizen van Rijklof van Goens ... 1648-1654 as 'unquestionably the most important set of primary sources for the midseventeenth-century court of Mataram'. De Graaf's consecutive series of books on the history of Mataram in the seventeenth century is praised because 'English, Dutch and Portuguese sources were here allied to Javanese works to produce a convincing narrative of the reign'. He mildly notes some of the limitations of De Graaf's scholarship: 'Thorny problems of analysis and interpretation were perhaps not always given the attention which they deserved and of Javanese sources his mastery was more limited.' These are two of the areas where Ricklefs strove, with remarkable success, to improve on his predecessor. Like De Graaf, however, he always remained suspicious of the historiography of broad vistas and wide perspectives and preferred to concentrate narrowly on what the sources told (or could be made to tell). Much of his work, with its painstakingly detailed analysis of Javanese manuscripts and voc archives, is reminiscent of the best work of his Dutch predecessors rather than the grand overviews or more speculative interpretative work of his Australian and American colleagues.

For many present (and, I expect, future) students of Indonesian history and politics, Ricklefs is first of all the author of $A$ history of modern Indonesia, which first appeared in 1981 and which he kept revising and updating in the 
light of new developments in the country and new insights in research. This was his first major publication as a professor of history at Monash University, staking out his area of expertise. It was also, in a sense, the successor to yet another work by De Graaf, Geschiedenis van Indonesië (1949), which he called (in the 1985 obituary) 'the most authoritative general textbook on Indonesian history until overtaken in some areas by new research in the 1970s and [still] a work which serious students of Indonesian history consult'. That was a generous assessment; De Graaf's unwillingness to take Indonesian nationalism and the independence movement seriously stood in the way of understanding twentieth-century developments. Ricklefs's own History was balanced and judicious in its treatment of controversial issues of the colonial period as well as post-independence conflicts and has, for four decades, remained by far the best introduction to the subject as well as a useful work of reference.

As readers of this book are aware, 'modern Indonesia' was for Ricklefs defined by the process of Islamization. The opening sentence sounds like a programmatic statement: 'The spread of Islam is one of the most significant processes of Indonesian history, but also one of the most obscure.' Ricklefs also wrote on other aspects of Indonesian history, but efforts to elucidate the vagaries of the process of Islamization and its modalities remained central to his research.

In an early article, titled 'Six centuries of Islamization in Java' (1979b), we find a number of ideas that he was to develop further in his later work. Islamization was not an event occurring at a particular time but a process that, once started, continued through the centuries without ever being completed. The adoption of Islam by the Javanese did not mean that they shed their previous beliefs and practices. Rather, Islam was embraced as an enrichment of the existing repertoire of devotional exercises and spiritual techniques for attaining supernatural powers: 'The new faith may have been a means of tapping another source of supernatural energy.' However, '[f] or much of the populace of Central Java, the Goddess of the Southern Ocean undoubtedly was the most important spiritual force in their lives, as she is still today'. And yet, '[b]eing Muslims, the Javanese were potentially susceptible to pressures for greater Islamic orthodoxy'. The late nineteenth and the twentieth century were marked by movements for the purification of Islamic belief and practice and defensive reactions to protect existing customs from the reformists' zeal. With some hyperbole, he asserted that the nineteenth century was one of the least-studied periods in all of Javanese history, pointing out one of the gaps that he was later to fill with the trilogy Mystic synthesis (2006), Polarising Javanese society (2007), and Islamisation and its opponents in Java (2012). More will be said about these important works below. 
Acquaintance with, and command of, all available primary sources, Javanese as well as European, is a sine qua non in Ricklefs's view of the role of the historian, and he himself engaged in some of the philological work that is a precondition of the historian's work. He worked with another Leiden scholar, P. Voorhoeve, on an inventory of the Indonesian manuscripts in various collections in Great Britain (1977), edited and translated major Javanese sources $(1967 \mathrm{~b}, 1978)$ and published several papers on variation and development in Javanese babad and other texts (1971, 1979a, and half a dozen other articles). And he helped his teachers De Graaf and Pigeaud to publish a controversial but fascinating source on the role of Chinese Muslims in the early phases of the Islamization of Java (1984).

This text, which the two Dutch scholars titled Malay annals of Sermarang and Cĕrbon, had first appeared in print two decades earlier as an appendix in a quaint, polemical book by the Batak writer M.O. Parlindungan, Tuanku Rao (1964). Parlindungan, who throughout the book makes a very unreliable impression, claimed that this text originated in manuscripts that an elusive Dutch official had taken from a Chinese temple in Semarang. The attribution of Islamization to Chinese influence, and especially the assertion that several of the wali sanga as well as the first Muslim ruler of Demak had been Chinese, was not very welcome among Indonesian Muslims. The issue became a major controversy when the historian Slametmuljana adopted this thesis as the core of his revisionist history of the fall of Majapahit and the rise of Islam in Java, as a result of which his book was banned. ${ }^{1}$ De Graaf and Pigeaud, who in 1974 had jointly published their study of the first Muslim polities in Java on the basis of an exhaustive survey of European and Javanese sources (De Graaf and Pigeaud 1974), were convinced that Chinese Muslims had played a more important role in the beginnings of Islamization than could be gleaned from Javanese sources. They found enough credible material in Parlindungan's text to persuade them that it must be based on some genuine chronicles. Their colleagues in Leiden, on the other hand, were convinced the entire text was a hoax-witness the scathing remarks on the subject by G.W.J. Drewes in his obituary of Pigeaud (Drewes 1989, especially pp. 212-3). They refused to publish De Graaf and Pigeaud's edition and erudite analysis in the KIT LV's Verhandelingen series in which their earlier work had appeared. Ricklefs then stepped in and published the 22o-page work, with an editor's introduction and some additional comments, in the Monash Papers series—as one reviewer (Reid) noted,

1 Slametmuljana 1968. In a changed political climate, both Slametmuljana's and Parlindungan's books were reprinted by the NU-affiliated publisher LKiS in Yogyakarta, in 2005 and 2007 respectively. 
'out of piety toward these two distinguished Javanists rather than a desire to authenticate Parlindungan'. ${ }^{2}$

Time has worked in favour of this text. The Chinese ancestry of Javanese saints became a less problematic issue among Indonesia's traditionalist Muslims, and more scholars came to accept that in spite of Parlindungan's inherent untrustworthiness there was a genuine core to his text. This was, to some extent, confirmed by other Chinese sources that could not have been available to Parlindungan (Wade 2010:366-408, esp. 396-7). In 1998 Ricklefs oversaw and carefully edited the Indonesian translation of the book, which no longer appeared to be controversial.

Meanwhile Ricklefs continued work on the major research project on which he had embarked soon after completing his dissertation. Judging that the sixteenth and seventeenth centuries in Javanese history were adequately covered by existing studies by De Graaf and Pigeaud, he focused on the almost unexplored Kartasura period (168o-1746). He soon discovered that the sheer volume of primary source materials in Dutch archives as well as in Javanese manuscript collections made this a gargantuan task. De Graaf confided that he too had once worked on Kartasura but 'had gone under in the flood of evidence', and gave him his own copious notes extracted from voc documents. Ricklefs worked on these materials intermittently for two decades, publishing an annotated edition and translation of a major Javanese source for the period in 1978, a compilation of economic and demographic data from Dutch sources in 1986 and ultimately completing the project with the two densely written, sophisticated studies War, culture and economy in Java, 1677-1726 (1993) and The seen and unseen worlds in Java, 1726-1749 (1998). Another two decades later, the historical narrative was pushed further in Soul catcher, the biography of Mangkunagara I, the rebel prince born in the court of Kartasura who fought the rival rulers of Yogyakarta and Surakarta (his close relatives) as well as the voc and established the royal house of Mangkunagaran (2018a). All three volumes are elegantly written exemplars of superb scholarship, in which the author demonstrates his unrivalled command of the Javanese and European sources and subtle understanding of Javanese culture and politics, and explodes many of the received ideas about the relations between Javanese and Europeans during the period.

The most remarkable of these works is Seen and unseen worlds, which stands out among Ricklefs's other publications for its felicitous treatment of the nexus of mysticism and politics. The political developments of the reign of Paku-

2 The controversies surrounding Parlindungan's text are narrated in detail in Kumar's (1987) thorough review. See also Reid 1989:508-9. 
buwana II are analysed through the prism of Javanese mystical literature and its 'magical' uses. The entire book deals with texts that were considered sacred and spiritually potent, the reading, reciting or recreating of which could mobilize the forces inherent in them for protection. The real protagonist of the book, rather than the young king himself, is his grandmother, the formidable Ratu Pakubuwana, who strove to protect the realm and turn her grandson into the ideal Sufi-King by having such sacred Islamic texts rewritten and undertaking other occult efforts.

Appropriately, for a book focusing on the occult power of sacred texts, the spirit of the great scholar of Javanese literature, P.J. Zoetmulder, looms large over it, and Ricklefs dedicated it to his memory. Both in the analysis of the Javanese texts, which belong to the so-called suluk literature, and in his alertness to the 'magical' properties ascribed to writing and reciting them, he acknowledges his debt to the Jesuit sage of Yogyakarta, whom he had continued to consult as his guru for thirty years. Judging that Zoetmulder's 1935 dissertation on suluk literature remained unsurpassed, after more than half a century, as a study of Javanese Islamic mysticism but was almost inaccessible to nonDutch readers, Ricklefs published an edited translation of this work as a tribute to the master and a preparation for his own study. Appropriately again, this translation appeared at the KITLV Press in the year of Zoetmulder's death, and the translator's introduction became an unintended obituary (1995).

Early in the new millennium, and perhaps inspired by the post-Soeharto reform period in Indonesia and the revival of debates and contestations on which the New Order had long kept a lid, Ricklefs began thinking of an ambitious new project that would trace the process of Islamization and the associated cultural and political struggles from the beginnings of Mataram to the present day. He intended three volumes, the first of which was to lean heavily on his earlier research and bring the narrative up to the early nineteenth century; the second would trace the emerging divide between strictly practising and nominal Muslims, leading to the major political cleavage in the early independence period; and the third was to focus on the victorious march of orthodox Islam in Java after independence. A central concept in his view of the historical dynamic concerned the rise and fall of what he called the 'mystic synthesis', a widely shared acceptance, and actual performance, of the formal obligations of Islam in combination with a continuing belief in, and ritual engagement with, the Javanese spirit world.

In the book Mystic synthesis in Java (2006), he shows in great detail that the gradual adoption of Islamic obligations and Islam's transcendental cosmology was by no means a unilinear process. The royal persons who best embodied the synthesis, Ratu Pakubuwana, Mangkubumi, and Mangkunagara I-each 
the subject of other books by Ricklefs-faced enemies, and had successors, who were much less committed to Islamic piety. For much of the time, the courts faced opposition from internal and external rebels who identified more strongly with Islam. These rebels were recognizable by their white dress, and were enumerated in the babad literature as kaum ('religious folk'), ulama, kétib (preachers), and santri (religious students). The actual beliefs and religious practices of the various groups of 'white people' may have varied widely; what they all had in common, however, was their opposition to collaboration with the kafir Europeans - a matter on which even the most pious of Javanese rulers appeared to be rather pragmatic. By the early nineteenth century, on the eve of true European colonial rule over Java, Ricklefs asserts, a mature form of the mystic synthesis, as exemplified in the Sërat Cĕnthini and the life of Dipanagara, had been achieved as the dominant mode of religious identity-'at least in aristocratic circles and [...] probably more widely as well'. Javanese were buried as Muslims, not cremated as in Hindu-Javanese times. The young were circumcised as a sign of Muslim identity. Men performed Muslim prayers, not only at the Friday service but also the regular five daily prayers (at least occasionally). Most Javanese fasted during Ramadan and all abstained from pork. Some performed the hajj pilgrimage to Mecca, which connected Java to the wider Islamic world. At the same time, the deities of the wayang, Hindu-Javanese kings, the Goddess of the South Sea, and other local spirits remained as important to the Javanese as the Muslim saints. Royals traced their descent from Adam through a dual genealogy: a lineage on the right through Muslim prophets, saints, and rulers, and a lineage on the left through the deities of the wayang and the Hindu-Javanese kings.

The second volume of the trilogy, Polarising Javanese society (2007), argues that the dichotomy of santri and abangan, made famous by Geertz, was a relatively recent phenomenon resulting from developments in the nineteenth century. The abangan formed a new social category, not mentioned in any indigenous or foreign sources before the mid nineteenth century. The 'white folk', putihan (Geertz's santri), are mentioned earlier but had become more numerous in the nineteenth century; colonial government officials now compiled statistics showing the increase of religious functionaries and hajj pilgrims. Religious schools, pesantren, another new phenomenon, were now also noticed and counted. The progress of 'white' Islam caused unease among some of the Javanese. Adducing a wide range of new sources, including unpublished missionaries' reports and the first Javanese periodical Bramartani, Ricklefs subtly documents the birth of the abangan among the peasantry and anti-Islamic responses among the elite as the movement away from an earlier acceptance of Islam. The emergence of the first Christian communities in Java is, in his 
analysis, another aspect of this drift away from Islam and search for alternative sources of ngelmu, occult knowledge.

The twin modernizing factors driving the process of polarization, European influence and Islamic reform, loom even larger over the final volume, Islamisation and its opponents (2012). The narrative is even more complex here, as Ricklefs documents the struggle of putihan and abangan through the final decade of Dutch rule, war, and revolution, and the political vicissitudes of independent Indonesia. Alongside written sources, as time progresses he relies increasingly on his own interviews and observations and the work of young Indonesian scholars. For the developments of the post-Soeharto period, local collaborators based in Solo, Yogyakarta, Kediri, and Surabaya, the four places he had chosen to focus on, assisted in overall observations, interviews, and data collection. The opponents of deeper Islamization, who in the 195os had still seemed the strongest political and cultural force, had dwindled to a small minority. The greater freedom of the post-Soeharto period did not, as many observers had expected, lead to a revival of abangan and elite forms of kebatinan, Javanese mysticism. The book is an empirically rich and nuanced account of the decline and virtual disappearance of the abangan and the remarkable success of the many varieties of reformist, modernist, puritan, and political Islam.

Merle Ricklefs leaves an impressive and remarkably coherent oeuvre behind, testimony to an untiring work ethic, discipline, and focus. All this pioneering research was carried out alongside his regular teaching obligations and mentoring of young, especially Indonesian, scholars. Several of his Indonesian PhD students now hold important academic positions in their country. Merle did not shy away from administrative responsibilities and other services to the scholarly community either. He served as Director of ANU's School of Pacific Studies (1993-1998) and of the Melbourne Institute of Asian Languages and Societies (1998-2006) and took part in several evaluations of international research institutes.

He received much international appreciation for his merits. In 1989 he was elected a fellow of the Australian Academy of the Humanities, and in 2010 he was made an honorary member of the KITLV. In 2015 the Association for Asian Studies awarded him the George McT. Kahin Prize, and in 2016 the Indonesian Ministry of Education and Culture presented him with its cultural award (Penghargaan Kebudayaan). In 2017 he was made a member of the Order of Australia, the highest award for outstanding achievement and service in that country. 


\section{References}

Drewes, G.W.J. (1989). 'In memoriam Theodoor Gautier Thomas Pigeaud', Bijdragen tot de Taal-, Land- en Volkenkunde 145-2/3:201-13.

Graaf, H.J. de and Th.G.Th. Pigeaud (1974). De eerste Moslimse vorstendommen op Java: Studiën over de staatkundige geschiedenis van de 15 de en 16 de eeuw. 's Gravenhage: Nijhoff.

Kumar, Ann L. (1987). 'Islam, the Chinese, and Indonesian historiography - a review article', Journal of Asian Studies 46-3:603-16.

Parlindungan, Mangaradja Onggang (1964). Pongkinangolngolan Sinambela gelar Tuangku Rao: Terror agama Islam mazhab Hambali di tanah Batak, 1816-1833. Djakarta: Tandjung Pengharapan.

Reid, Anthony (1989). Review of M.C. Ricklefs (ed.), Chinese Muslims in Java in the fifteenth and sixteenth centuries: The Malay annals of Sĕmarang and Cĕrbon, The American Historical Review 94-2:508-9.

Slametmuljana, R.B. (1968). Runtuhnja keradjaan Hindu Djawa dan timbulnja negara2 Islam di Nusantara. Djakarta: Bhratara.

Wade, Geoff (2010). 'Early Muslim expansion in South-East Asia, eighth to fifteenth centuries', in: David O. Morgan and Anthony Reid (eds), The new Cambridge history of Islam. Vol. 3: The eastern Islamic world, eleventh to eighteenth centuries. Cambridge: Cambridge University Press.

\section{Select List of Publications by Merle C. Ricklefs}

'Land and the law in the epigraphy of tenth-century Cambodia', Journal of Asian Studies 26-3:411-2o, 1967a.

with Soepomo Poedjosoedarmo. 'The foundation of Surakarta: A translation from the Babad Gianti, Indonesia 4:88-108, 1967b.

'On the authorship of Leiden Cod.Or. 2191, Babad Mangkubumi', Bijdragen tot de Taal-, Land- en Volkenkunde 127-2:264-73, 1971.

Jogjakarta under Sultan Mangkubumi 1749-1792. A history of the division of Java. London: Oxford University Press, 1974a. [Book version of the $1973 \mathrm{PhD}$ dissertation.]

'Dipanagara's early inspirational experience', Bijdragen tot de Taal-, Land- en Volkenkunde 130-2/3:227-58, 1974b.

with P. Voorhoeve. Indonesian manuscripts in Great Britain: A catalogue of manuscripts in Indonesian languages in British public collections. Oxford: Oxford University Press, 1977. [London Oriental Bibliographies, vol. 5.]

Modern Javanese historical tradition: A study of an original Kartasura chronicle and related materials. London: School of Oriental and African Studies, 1978. [Annotated edition and translation of the Babad ing Sangkala.] 
'The evolution of the Babad Tanah Jawi texts', Bijdragen tot de Taal-, Land- en Volkenkunde 135-4:435-54, 1979a.

'Six centuries of Islamization in Java', in: Nehemia Levtzion (ed.), Conversion to Islam, pp. 10o-28. New York: Holmes and Meier, 1979b.

A history of modern Indonesia, ca. 1300 to the present. Basingstoke: Macmillan, 1981. [Revised editions: 1993, 2001, 2008.]

Chinese Muslims in Java in the ffteenth and sixteenth centuries: Malay annals of Sĕmarang and Cĕrbon, by H.J. de Graaf and Th.G.Th. Pigeaud. Ed. M.C. Ricklefs. Clayton: Centre of Southeast Asian Studies, Monash University, 1984. [Monash Papers on Southeast Asia 12; Indonesian translation: Cina Muslim diJawa abad XV dan XVI: antara historisitas dan mitos. Yogyakarta: Tiara Wacana, 1998.]

'In memoriam Dr. H.J. de Graaf', Bijdragen tot de Taal-, Land- en Volkenkunde 1412/3:191-201, 1985 .

'Some statistical evidence on Javanese social, economic and demographic history in the later seventeenth and eighteenth centuries', Modern Asian Studies 20-1:1-32, 1986.

War, culture and economy in Java, 1677-1726. Asian and European imperialism in the early Kartasura period. Sydney: Asian Studies Association of Australia in association with Allen \& Unwin, 1993.

Pantheism and monism in Javanese suluk literature: Islamic and Indian mysticism in an Indonesian setting, by P.J. Zoetmulder, s.J. Ed. and transl. M.C. Ricklefs. Leiden: KITLV Press, 1995 .

The seen and unseen worlds in Java, 1726-1749. History, literature and Islam in the court of Pakubuwana II. Sydney and Honolulu: Asian Studies Association of Australia in association with Allen \& Unwin and University of Hawai'i Press, 1998.

Mystic synthesis in Java: A history of Islamization from the fourteenth to the early nineteenth centuries. Norwalk, CT: EastBridge, 2006.

Polarising Javanese society: Islamic and othervisions (c. 1830-1930). Singapore: NUS Press, 2007.

Islamisation and its opponents in Java, c. 1930 to the present. Singapore: NUS Press, 2012. Soul catcher:Java's fiery Prince Mangkunagara I, 1726-95. Singapore: NUS Press, 2018a.

'The perils of hybridity in 19th-century Java: Ronggawarsita's reputation, animated debates in Bramartani, and the probable origins of Javanese acrostics; with a postscript on Purwalĕlana', Archipel 96:103-27, 2018b.

'The strange journey of Latawalujwa in Java, from two pre-Islamic goddesses to an elastic term for God', Archipel 98:109-19, 2019. 